\title{
CHARACTERIZATION OF THE MARCH 2004 TANK 40 (SLUDGE BATCH 3) DIP SAMPLES
}

J. M. Pareizs

T. L. Fellinger

D. R. Click

May 2004 
This document was prepared in conjunction with work accomplished under Contract No. DE-AC09-96SR18500 with the U. S. Department of Energy.

\section{DISCLAIMER}

This report was prepared as an account of work sponsored by an agency of the United States Government. Neither the United States Government nor any agency thereof, nor any of their employees, makes any warranty, express or implied, or assumes any legal liability or responsibility for the accuracy, completeness, or usefulness of any information, apparatus, product or process disclosed, or represents that its use would not infringe privately owned rights. Reference herein to any specific commercial product, process or service by trade name, trademark, manufacturer, or otherwise does not necessarily constitute or imply its endorsement, recommendation, or favoring by the United States Government or any agency thereof. The views and opinions of authors expressed herein do not necessarily state or reflect those of the United States Government or any agency thereof.

This report has been reproduced directly from the best available copy.

Available for sale to the public, in paper, from: U.S. Department of Commerce, National Technical Information Service, 5285 Port Royal Road, Springfield, VA 22161, phone: (800) 553-6847, fax: (703) 605-6900

email: orders@ntis.fedworld.gov

online ordering: http://www.ntis.gov/help/index.asp

Available electronically at http://www.osti.gov/bridge

Available for a processing fee to U.S. Department of Energy and its contractors, in paper, from: U.S. Department of Energy, Office of Scientific and Technical Information, P.O. Box 62, Oak Ridge, TN 37831-0062,

phone: (865)576-8401,

fax: (865)576-5728

email: $\underline{\text { reports@ adonis.osti.gov }}$ 
WSRC-TR-2004-00208

Revision 0

Key Words: DWPF, TTANK 40, SB3, SHIELDED CELLS

Retention: PERMANENT

\section{CHARACTERIZATION OF THE MARCH 2004 TANK 40 (SLUDGE BATCH 3) DIP SAMPLES}

J. M. Pareizs

T. L. Fellinger

D. R. Click

May 2004 
This page was intentionally left blank 


\section{EXECUTIVE SUMMARY}

The Defense Waste Processing Facility (DWPF) has begun processing Sludge Batch 3 (SB3). Sludge Batch 3 consists of the heel in Tank 40 (Sludge Batch 2), the contents of Tank 51, and a Np stream from H Canyon. Two dip samples were pulled from Tank 40 in March 2004 after the initial Tank 51 to 40 transfer and the first transfer of $\mathrm{Np}$ material from $\mathrm{H}$ Canyon. These samples were combined into one sample and characterized by the Savannah River Technology Center (SRTC). The purpose of this characterization is to provide DWPF with a current Tank 40 (SB3) composition for comparison to Sludge Receipt and Adjustment Tank (SRAT) receipt analyses as they transition to the new sludge batch. The key analytical results for this sample are given below.

$\begin{array}{llll}\text { Slurry Density } & 1.185 \mathrm{~g} / \mathrm{mL} \text { of slurry } & \text { Coal }(\mathrm{mg} / \mathrm{kg}) & 71-240 \mathrm{mg} / \mathrm{kg} \text { of slurry } \\ \text { Supernate Density } & 1.048 \mathrm{~g} / \mathrm{mL} \text { of supernate } & \text { Base Equivalents } & 0.43 \mathrm{Eq} / \mathrm{L} \text { slurry of slurry } \\ \text { Total Solids } & 20.0 \mathrm{wt} \% \text { of slurry } & \mathrm{Al} & 6.04 \mathrm{wt} \% \text { of total solids } \\ \text { Soluble Solids } & 5.17 \mathrm{wt} \% \text { of slurry } & \mathrm{Ca} & 1.66 \mathrm{wt} \% \text { of total solids } \\ \text { Insoluble Solids } & 14.8 \mathrm{wt} \% \text { of slurry } & \mathrm{Fe} & 19.4 \mathrm{wt} \% \text { of total solids } \\ \text { Fluoride } & 235 \mathrm{mg} / \mathrm{kg} \text { of slurry } & \mathrm{Mg} & 1.67 \mathrm{wt} \% \text { of total solids } \\ \text { Formate } & <1,000 \mathrm{mg} / \mathrm{kg} \text { of slurry } & \mathrm{Mn} & 3.95 \mathrm{wt} \% \text { of total solids } \\ \text { Chloride } & <200 \mathrm{mg} / \mathrm{kg} \text { of slurry } & \mathrm{Na} & 12.1 \mathrm{wt} \% \text { of total solids } \\ \text { Nitrite } & 15,500 \mathrm{mg} / \mathrm{kg} \text { of slurry } & \mathrm{Ni} & 1.09 \mathrm{wt} \% \text { of total solids } \\ \text { Nitrate } & 10,500 \mathrm{mg} / \mathrm{kg} \text { of slurry } & \mathrm{S} & 0.288 \mathrm{wt} \% \text { of total solids } \\ \text { Phosphate } & <1,000 \mathrm{mg} / \mathrm{kg} \text { of slurry } & \mathrm{U} & 6.99 \mathrm{wt} \% \text { of total solids } \\ \text { Sulfate } & 1,690 \mathrm{mg} / \mathrm{kg} \text { of slurry } & \text { Consistency } & 5.6 \mathrm{cp} \\ \text { Oxalate } & 1,030 \mathrm{mg} / \mathrm{kg} \text { of slurry } & \text { Yield Stress } & 33 \mathrm{dynes} / \mathrm{cm}^{2}\end{array}$

The conclusions from this analysis are:

- Coal content of the Tank 40 sample was similar to that predicted using analysis of the Tank 51 qualification sample.

- Most, if not all, the sulfur was soluble and in the form of sulfate. Ion Chromatography (IC) analysis of the water dilution of the slurry is adequate for sulfate determination in the SB3 sample.

- Most, if not all, the oxalate was soluble. IC analysis of the water dilution of the slurry is adequate and the acid strike method is not necessary for oxalate determination in SB3.

- The yield stress and the consistency for the March 2004 SB3 sample is within the DWPF Operating Region. 


\section{TABLE OF CONTENTS}

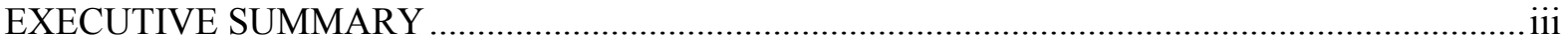

LIST OF FIGURES

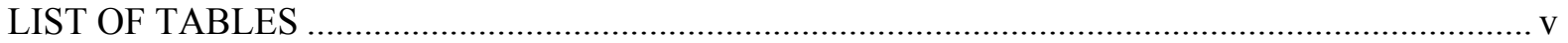

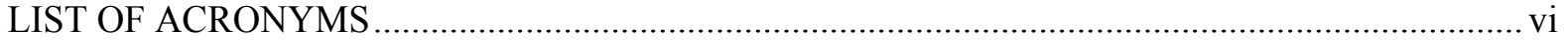

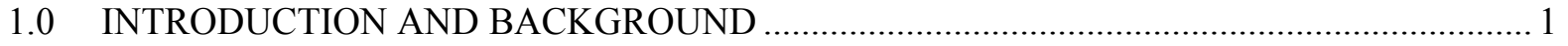

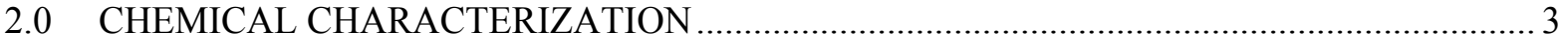

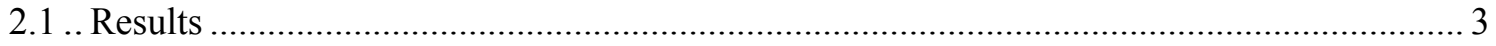

2.2 .. Comparison of Methods for Sulfate and Oxalate Determination ...................................... 8

2.3 .. Comparison of SB3 Sample Results to Tank Farm Predictions and DWPF SRAT Receipt

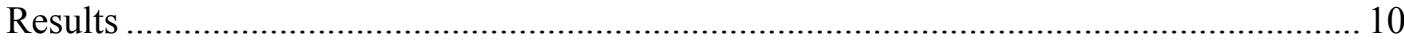

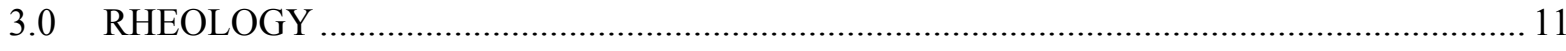

3.1 .. Description of the Apparatus Used for the Rheological Measurements............................. 11

3.2 .. March 2004 SB3 Sludge Slurry Observations and Rheology Measurements ..................... 11

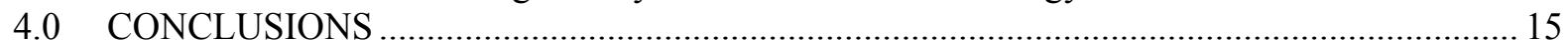

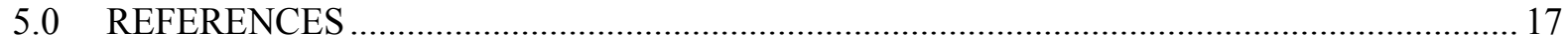




\section{LIST OF FIGURES}

Figure 2-1. Graphical Comparison of the Average of Four Sulfate Determinations With 95\% Confidence Intervals 8

Figure 2-2. Graphical Comparison of the Average of Three Oxalate Determinations With 95\% Confidence Intervals

Figure 3-1. Uncorrected Flow Curve for the March 2004 SB3 Sludge Slurry Sample Compared to the DWPF Operating Region

\section{LIST OF TABLES}

Table 2-1. Density and Weight Percent Solids of the Tank 40 Dip Sample ....................................... 3

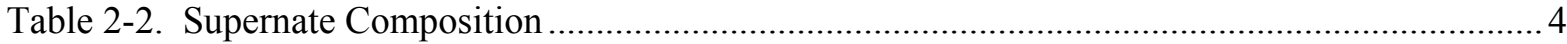

Table 2-3. Anions and Base Equivalents of the Tank 40 Slurry …................................................. 5

Table 2-4. Experimental Results of the Thermogravimetric Analysis of Sieved Solids from the March 2004 Tank 40 Sample . .5

Table 2-5. Coal Content of the Tank 40 Sludge Batch 3 and Tank 51 Qualification Samples ............. 6

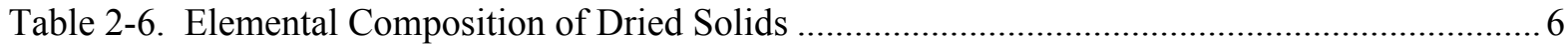

Table 2-7. Comparison between Supernate Analysis and Water Dilution of Slurry ............................ 7

Table 2-8. Comparison of Sludge Batch 3 Supernate Results to Tank Farm Predictions ................... 10

Table 2-9. Comparison of SB3 Sample Results to DWPF SRAT 275 Receipt Analyses ................... 10

Table 3-1. Programming Times and Shear Rate Ranges Selected for the Sludge Slurry and

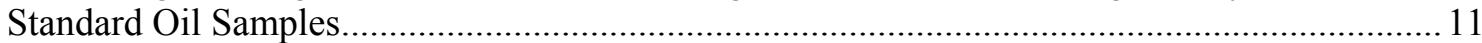

Table 3-2. Summary of the Results Obtained from the SB3 Sludge Slurry Samples Compared to the SRTC SB3 Qualification Sample and the DWPF Operating Region................................... 13 


\section{LIST OF ACRONYMS}

DWPF

IC

ICP-ES

NIST

SB3

SRAT

SRTC

TGA
Defense Waste Processing Facility

Ion Chromatography

Inductively Coupled Plasma Emissions Spectroscopy

National Institute of Standards and Technology

Sludge Batch 3

Slurry Receipt Adjustment Tank

Savannah River Technology Center

Thermogravimetric Analysis 


\subsection{INTRODUCTION AND BACKGROUND}

The Defense Waste Processing Facility (DWPF) has begun processing Sludge Batch 3 (SB3). Sludge Batch 3 consists of the heel in Tank 40 (Sludge Batch 2), the contents of Tank 51, and a Np stream from H Canyon.

Two dip samples were pulled from Tank 40 after the initial Tank 51 to 40 transfer and the first transfer of $\mathrm{Np}$ material from H Canyon ${ }^{1}$. These samples were combined into one sample and characterized by SRTC. The purpose of this characterization is to provide DWPF with a current Tank 40 (SB3) composition for comparison to SRAT receipt analyses as they transition to the new sludge batch.

${ }^{1}$ Initial plans were to transfer all of Tank 51 and all of a Np stream from H Canyon to Tank 40 prior to Sludge Batch 3 processing. Due to operational problems, only about $70 \%$ of the Tank 51 to 40 transfer and $55 \%$ of the $\mathrm{H}$ Canyon to Tank 40 transfers were completed. Final transfers are planned for late spring of this year. 
WSRC-TR-2004-00208

Revision 0

This page intentionally left blank. 


\subsection{CHEMICAL CHARACTERIZATION}

\subsection{Results}

The two dip samples from Tank 40 were received by SRTC in March 2004 and combined into one sample of approximately $350 \mathrm{~mL}$. Chemical and physical analyses, including rheology, were performed using aliquots of slurry subsampled from this combined sample. To obtain supernate, a portion of slurry was filtered using a $0.45 \mu \mathrm{m}$ Nalgene ${ }^{\circledR}$ filter.

Slurry and supernate densities were determined by weighing slurry and supernate in vessels of known volume. Weight percent total solids were determined by drying slurry samples. Weight percent dissolved solids (solids in the supernate) were measured by drying supernate samples. The measured weight percent total and dissolved solids were then used to calculate the weight percent soluble and insoluble solids in the slurry:

$$
W_{i s}=\frac{W_{t s}-W_{d s}}{100-W_{d s}} \cdot 100 \text { and } W_{s s}=\frac{100-W_{t s}}{100-W_{d s}} \cdot W_{d s}
$$

where,

$W_{t s}=$ weight percent solids in the slurry (weight percent total solids)

$W_{d s}=$ weight percent solids in the supernate (weight percent dissolved solids)

$W_{i s}=$ weight percent insoluble solids in the slurry

$W_{s s}=$ weigh percent soluble solids in the slurry.

Weight percent calcined solids were determined by heating slurry samples to $1000^{\circ} \mathrm{C}$ in alumina crucibles. Density and weight percent solids results of the slurry are presented in Table 2-1.

Table 2-1. Density and Weight Percent Solids of the Tank 40 Dip Sample

\begin{tabular}{|c|c|}
\hline & $\begin{array}{l}\text { Result With 95\% Confidence } \\
\text { Interval }\end{array}$ \\
\hline Slurry Density $(\mathrm{g} / \mathrm{mL})^{\mathrm{a}}$ & $1.185 \pm 0.018$ \\
\hline Supernate Density $(\mathrm{g} / \mathrm{mL})^{a}$ & $1.048 \pm 0.002$ \\
\hline $\begin{array}{l}\mathrm{Wt} \% \text { Total Solids } \\
\text { (Wt\% solids in slurry) }\end{array}$ & $20.0 \pm 1.9$ \\
\hline $\begin{array}{l}\text { Wt } \% \text { Dissolved Solids } \\
\text { (Wt } \% \text { solids in supernate) }\end{array}$ & $6.07 \pm 0.03$ \\
\hline $\begin{array}{l}\mathrm{Wt} \% \text { Soluble Solids }{ }^{\mathrm{d}} \\
\text { (Wt\% soluble solids in slurry) }\end{array}$ & $5.17 \pm 0.18$ \\
\hline $\begin{array}{l}\text { Wt\% Insoluble Solids }{ }^{\mathrm{d}} \\
\text { (Wt\% insoluble solids in } \\
\text { slurry) }\end{array}$ & $14.8 \pm 2.0$ \\
\hline $\begin{array}{l}\mathrm{Wt} \% \text { Calcined Solids }{ }^{\mathrm{e}} \\
(\mathrm{Wt} \% \text { calcined solids in slurry) }\end{array}$ & $17.4 \pm 0.2$ \\
\hline
\end{tabular}


Supernate was characterized by Ion Chromatography (IC) for anions and Inductively Coupled Plasma Emissions Spectroscopy (ICP-ES) for sodium, the primary cation in the supernate. IC provides quantification of the primary anions in the supernate except hydroxide. ICP-ES provides the elemental composition of the supernate. These results are given in Table 2-2. Presented are all the anions, excluding bromide, that are routinely reported by IC and the major cation - sodium.

Table 2-2. Supernate Composition

\begin{tabular}{lc}
\hline & $\begin{array}{c}\text { Concentration with } \\
95 \% \text { Confidence } \\
\text { Interval }(\mathrm{M})\end{array}$ \\
\hline Fluoride $^{\mathrm{a}}$ & $0.0109 \pm 0.0006$ \\
Formate $^{\mathrm{a}}$ & $0.0020 \pm 0.0001$ \\
Chloride $^{\mathrm{a}}$ & $<0.0009$ \\
Nitrite $^{\mathrm{a}}$ & $0.420 \pm 0.011$ \\
Nitrate $^{\mathrm{a}}$ & $0.191 \pm 0.010$ \\
Phosphate $^{\mathrm{a}}$ & $<0.0006$ \\
Sulfate $^{\mathrm{a}}$ & $0.0218 \pm 0.0007$ \\
Oxalate $^{\mathrm{a}}$ & $0.0160 \pm 0.0005$ \\
Sodium $^{\text {a }}$ & $1.00 \pm 0.02$ \\
\hline aad on four replicates &
\end{tabular}

Table 2-3 lists the anion composition and base equivalents (equivalents of acid needed to reach $\mathrm{pH}$ 7) of the Tank 40 slurry. The anions were determined by IC analysis of slurry diluted by a factor of 100 (nominally $1 \mathrm{~g}$ of slurry diluted to $100 \mathrm{~mL}$ ) with water. Solids in the slurry were allowed to settle to minimize solids uptake during sampling prior to submitting for IC analysis. The oxalate by acid strike was determined by IC analysis of slurry diluted with acid. The purpose of the acid strike is to dissolve any insoluble oxalate so it can be measured. 
Table 2-3. Anions and Base Equivalents of the Tank 40 Slurry

\begin{tabular}{|c|c|}
\hline & $\begin{array}{c}\text { Concentration in } \\
\text { Slurry with } 95 \% \\
\text { Confidence Interval } \\
(\mathrm{mg} / \mathrm{kg})\end{array}$ \\
\hline Fluoride $(\mathrm{mg} / \mathrm{kg})^{\mathrm{a}}$ & $235 \pm 84$ \\
\hline Formate $(\mathrm{mg} / \mathrm{kg})^{\mathrm{a}}$ & $<1,000$ \\
\hline Chloride $(\mathrm{mg} / \mathrm{kg})^{\text {a }}$ & $<200$ \\
\hline Nitrite $(\mathrm{mg} / \mathrm{kg})^{\mathrm{a}}$ & $15,500 \pm 900$ \\
\hline Nitrate $(\mathrm{mg} / \mathrm{kg})^{\mathrm{a}}$ & $10,500 \pm 600$ \\
\hline Phosphate $(\mathrm{mg} / \mathrm{kg})^{\text {a }}$ & $<1,000$ \\
\hline Sulfate $(\mathrm{mg} / \mathrm{kg})^{\mathrm{a}}$ & $1,690 \pm 240$ \\
\hline Oxalate $(\mathrm{mg} / \mathrm{kg})^{\mathrm{a}}$ & $1,030 \pm 110$ \\
\hline $\begin{array}{l}\text { Oxalate (Acid Strike) } \\
\qquad(\mathrm{mg} / \mathrm{kg})^{\mathrm{a}}\end{array}$ & $920 \pm 220$ \\
\hline $\begin{array}{l}\text { Base Equivalents }(\mathrm{Eq} / \mathrm{L} \\
\text { slurry) }{ }^{b}\end{array}$ & 0.43 \\
\hline
\end{tabular}

${ }^{a}$ Based on four replicates.

${ }^{\mathrm{b}}$ Based on two replicates. Because there were only two replicates, a confidence interval was not calculated.

Coal content was determined by thermogravimetric analysis (TGA) of slurry solids with a particle size greater than $38 \mu \mathrm{m}$. Maximum coal content was determined based on the total weight loss of these solids during TGA analysis. The minimum coal content was based on the weight loss of these solids attributed to fixed carbon. Experimental results are presented in Table 2-4. Coal content of the Tank 40 sample with a comparison to the Tank 51 qualification sample is presented in Table 2-5.

Table 2-4. Experimental Results of the Thermogravimetric Analysis of Sieved Solids from the March 2004 Tank 40 Sample

\begin{tabular}{cccc}
\hline & Weight of Solids & & Weight \% Loss Due \\
Weight of Slurry & Collected on Sieve & Total Weight \% Loss & to Fixed Carbon Loss \\
Sample Sieved $(\mathrm{g})$ & $(\mathrm{g})^{\mathrm{a}}$ & Upon TGA Analysis & Upon TGA Analysis \\
31.154 & 0.005 & 40.07 & 12.18 \\
\hline 30.089 & 0.036 & 16.19 & 0.88 \\
\hline 29.989 & 0.034 & 34.99 & 12.24 \\
\hline
\end{tabular}

${ }^{a}$ Solids collected on 400 mesh $(38 \mu \mathrm{m})$ sieve screen. 
Table 2-5. Coal Content of the Tank 40 Sludge Batch 3 and Tank 51 Qualification Samples

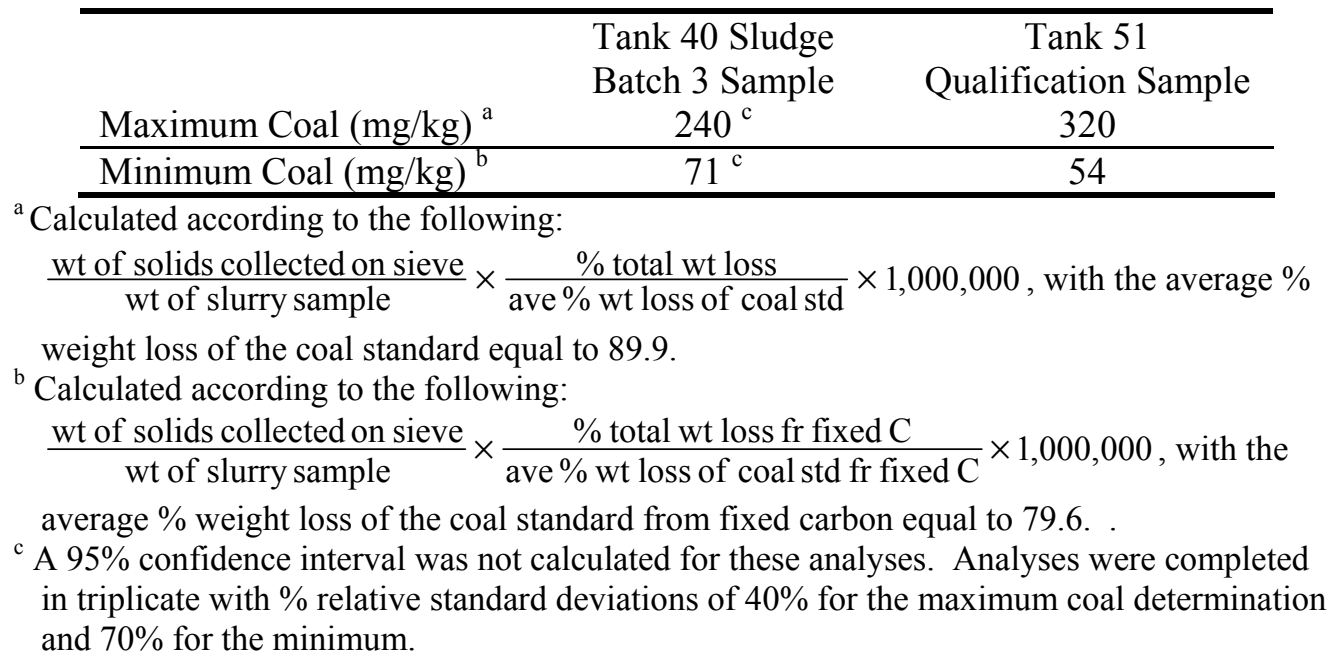

The measured Tank 40 coal concentration is similar to the predicted concentration ( $200 \mathrm{ppm}$ ) based upon the values obtained from the Tank 51 qualification sample multiplied by the ratio of sludge batch 2 to 3 blend now feeding the DWPF ${ }^{1,2,3}$. It is important to note, that if all $7000 \mathrm{lbs}$ of coal from the K Area sand filters was backwashed into Tank 7, the approximate coal concentration in Tank 40 would be 1000 ppm based upon the mass of slurry presently in Tank 40. It is estimated that only a small portion of the coal was sent to Tank $7^{4}$.

Table 2-6 gives the elemental composition of the dried slurry solids. Composition was determined by an aqua regia dissolution of dried solids. Included in the table are elements present at greater than $0.5 \mathrm{wt} \%$ of the solids plus sulfur. Although silicon may be present at greater than $0.5 \%$, it is not reported; aqua regia is not a suitable dissolution for silicon determination.

Table 2-6. Elemental Composition of Dried Solids

\begin{tabular}{cc}
\hline & $\begin{array}{c}\text { Wt\% of Total Solids } \\
\text { with 95\% Confidence } \\
\text { Interval }\end{array}$ \\
\hline $\mathrm{Al}$ & $6.04 \pm 0.23$ \\
$\mathrm{Ca}$ & $1.66 \pm 0.08$ \\
$\mathrm{Fe}$ & $19.4 \pm 1.7$ \\
$\mathrm{Mg}$ & $1.67 \pm 0.05$ \\
$\mathrm{Mn}$ & $3.95 \pm 0.11$ \\
$\mathrm{Na}$ & $12.1 \pm 0.8$ \\
$\mathrm{Ni}$ & $1.09 \pm 0.04$ \\
$\mathrm{~S}$ & $0.288 \pm 0.015$ \\
$\mathrm{U}$ & $6.99 \pm 0.32$ \\
\hline a Based on four aqua regia dissolutions of dried solids.
\end{tabular}

A comparison between supernate anion results (from Table 2-2) and the results from the water dilution of the slurry (from Table 2-3) is presented in Table 2-7. The supernate results were converted to a slurry basis using the supernate density, weight percent dissolved solids in the supernate, and weight percent total solids in the slurry: 
$C_{i}=\frac{M_{i} \cdot M W_{i}}{D_{\text {supn }}} \cdot \frac{\left(100-W_{t s}\right)}{\left(100-W_{d s}\right)} \cdot 1000$

or, using the calculated soluble solids,

$$
C_{i}=\frac{M_{i} \cdot M W_{i}}{D_{\text {supn }}} \cdot \frac{W_{s S}}{W_{d s}} \cdot 1000
$$

where,

$\mathrm{C}_{\mathrm{i}}$ is the concentration of $\mathrm{i}$ in the slurry $(\mathrm{mg} / \mathrm{kg})$

$M_{i}$ is the molarity of $i$ in the supernate $(\mathrm{mol} / \mathrm{L})$

$\mathrm{MW}_{\mathrm{i}}$ is the molecular weight of $\mathrm{i}(\mathrm{g} / \mathrm{mol})$

$\mathrm{W}_{\text {ts }}$ is the weight percent total solids in the slurry

$\mathrm{W}_{\mathrm{ds}}$ is the weight percent dissolved solids in the supernate

$\mathrm{W}_{\mathrm{ss}}$ is the weight percent soluble solids in the slurry

$\mathrm{D}_{\text {supn }}$ is the density of the supernate $(\mathrm{kg} / \mathrm{L})$

1000 is the conversion from $\mathrm{g}$ to $\mathrm{mg}$.

Table 2-7. Comparison between Supernate Analysis and Water Dilution of Slurry

\begin{tabular}{lcc}
\hline & $\begin{array}{c}\text { Concentration } \\
\text { Calculated from } \\
\text { Supernate Analysis } \\
\text { with 95\% Confidence } \\
\text { Interval }(\mathrm{mg} / \mathrm{kg})\end{array}$ & $\begin{array}{c}\text { Concentration from } \\
\text { Water Dilution of } \\
\text { Slurry with 95\% } \\
\text { Confidence Interval } \\
(\mathrm{mg} / \mathrm{kg})\end{array}$ \\
\hline Fluoride & $168 \pm 9$ & $235 \pm 84$ \\
Formate & $<80$ & $<1,000$ \\
Chloride & $<30$ & $<200$ \\
Nitrite & $15,700 \pm 500$ & $15,500 \pm 900$ \\
Nitrate & $9,620 \pm 550$ & $10,500 \pm 600$ \\
Phosphate & $<50$ & $<1,000$ \\
Sulfate & $1,700 \pm 70$ & $1,690 \pm 240$ \\
Oxalate & $1,140 \pm 50$ & $1,030 \pm 110$ \\
\hline
\end{tabular}

As shown in Table 2-7, there is good agreement between the concentrations calculated from the supernate results and the concentrations from the slurry dilution within the $95 \%$ confidence limits. It should also be noted that the precision for the supernate results is generally better than the results from the slurry dilution. The conclusion from this comparison is that a supernate analysis and a slurry dilution give comparable results for these anions in the SB3 sample. 


\subsection{Comparison of Methods for Sulfate and Oxalate Determination}

A comparison of the various methods for determining sulfate content in the slurry is given in Figure 2-1. Sulfate, on a slurry basis, was measured/calculated four ways:

- IC analysis of supernate - this method measures only soluble sulfate.

- IC analysis of water diluted slurry - this method measures soluble sulfate plus any insoluble sulfate dissolved in the dilution.

- ICP-ES analysis of supernate - this method measures soluble S; the result is converted to sulfate for comparison to IC results.

- ICP-ES analysis of dried solids - this method measures all the $\mathrm{S}$ in the slurry; the result is then converted to sulfate for comparison to IC results.

As can be seen from Figure 2-1, all of the methods yield a similar sulfate concentration in the slurry. This implies that, for this sample, all the sulfur is in the form of sulfate, and all the sulfate is soluble. These results are similar to earlier analyses of Tank 40 and Tank $51 .^{5}$ In these analyses it was shown that sulfur was soluble and in the form of sulfate for the Tank 40 and 51 samples.

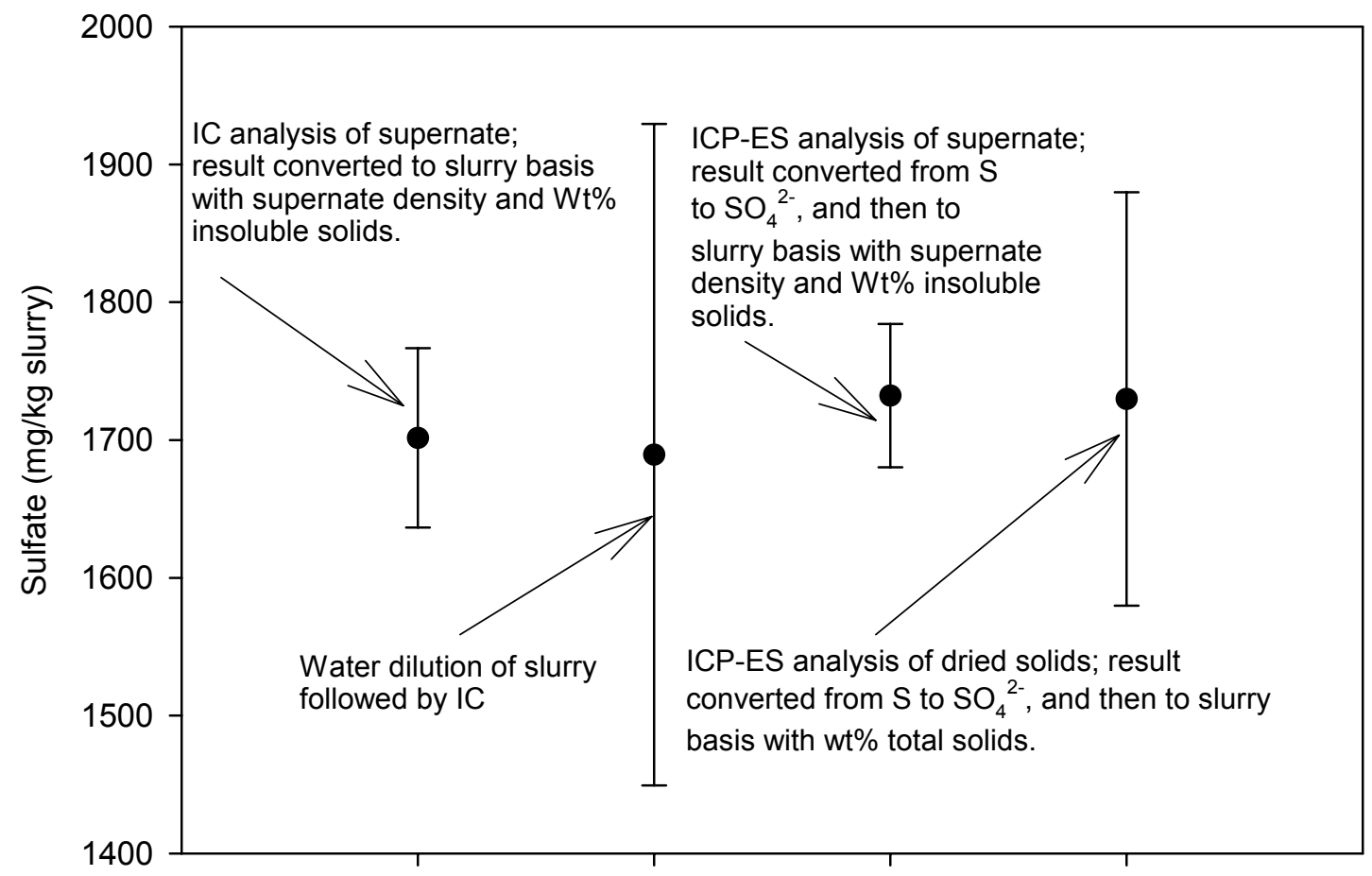

Figure 2-1. Graphical Comparison of the Average of Four Sulfate Determinations With 95\% Confidence Intervals 
A similar comparison of methods was completed for oxalate (see Figure 2-2). Three methods were compared:

- IC analysis of supernate - this method measures only the soluble oxalate.

- IC analysis of water diluted slurry - this method measures soluble oxalate plus any insoluble oxalate dissolved in the water dilution.

- IC analysis of acid strike of slurry - this method measures the soluble oxalate plus any additional oxalate dissolved by the acid in the slurry.

An examination of the results of the three methods shows that there is little, if any, insoluble oxalate in this sample. The acid strike method, designed to dissolve insoluble oxalate, actually gave a lower result than the other two methods. Note, however, that with the $95 \%$ confidence intervals taken into consideration, one cannot conclude that the acid strike result is significantly different than the other two methods. One can conclude that the acid strike method is less precise and is certainly not better than the other two methods for this SB3 sample. Therefore, it appears that the acid strike method is not necessary for oxalate quantification since no insoluble oxalate was identified.

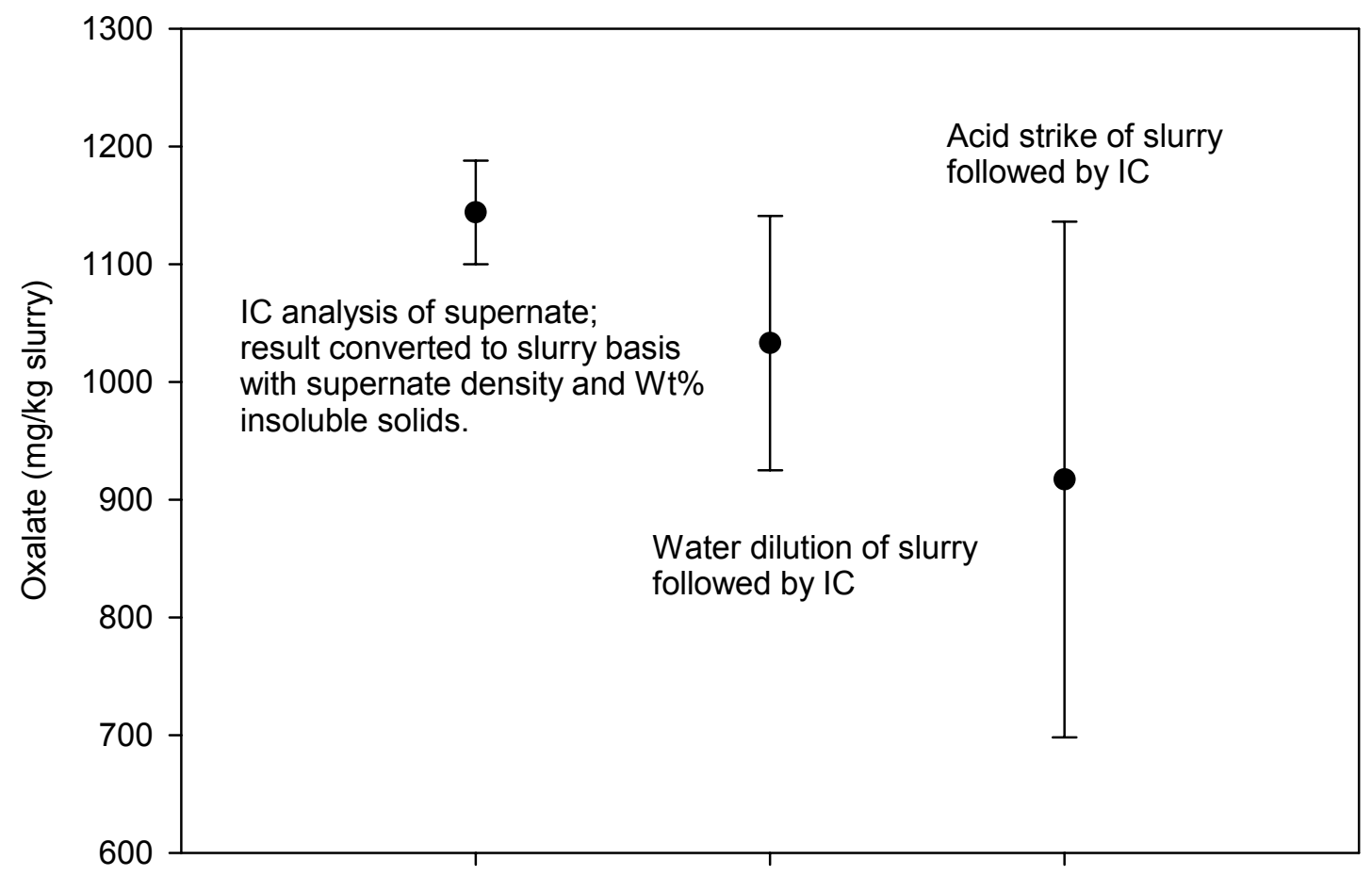

Figure 2-2. Graphical Comparison of the Average of Three Oxalate Determinations With 95\% Confidence Intervals 


\subsection{Comparison of SB3 Sample Results to Tank Farm Predictions and DWPF SRAT Receipt Results}

Table 2-8 shows a comparison between the SB3 sample supernate results and Tank Farm predictions. Except for sodium, results compare well, indicating that actual Tank Farm processing (transfers, etc.) occurred as planned. The sodium discrepancy is likely due to precipitation of sodium compounds. For the SB3 sample, if one converts the soluble sodium to a total solids basis, only $77 \%$ of the sodium is soluble.

Table 2-8. Comparison of Sludge Batch 3 Supernate Results to Tank Farm Predictions

\begin{tabular}{lcc}
\hline & $\begin{array}{c}\text { SB3 Supernate } \\
\text { Results }^{\text {a }}\end{array}$ & $\begin{array}{c}\text { Tank Farm } \\
\text { Prediction }^{\mathrm{b}}\end{array}$ \\
\hline Nitrite (M) & 0.42 & 0.44 \\
Nitrate (M) & 0.19 & 0.20 \\
Sulfate (M) & 0.022 & 0.023 \\
Oxalate (M) & 0.016 & 0.017 \\
Sodium (M) & 1.00 & 1.13 \\
\hline
\end{tabular}

${ }^{\text {a }}$ See Table 2-2.

${ }^{\mathrm{b}}$ Values taken from a spreadsheet from J. M. Gillam of Tank Farm Engineering.

Table 2-9 shows a comparison between the SB3 sample and DWPF SRAT Receipt analyses for batch 275. In comparing total solids, calcined solids, oxalate, sulfate, iron, sodium, and uranium, it appears that DWPF is nearly transitioned to the new sludge batch. Nitrite, nitrate, and base equivalents cannot be compared because these results are affected by the SRAT heel, which is higher in formate and nitrate, and lover in nitrite than incoming sludge.

Table 2-9. Comparison of SB3 Sample Results to DWPF SRAT 275 Receipt Analyses

\begin{tabular}{|c|c|c|}
\hline & SB3 Sample ${ }^{a}$ & $\begin{array}{l}\text { SRAT Receipt for } \\
\text { Batch } 275^{\text {b }}\end{array}$ \\
\hline Total Solids (wt\%) & 20.0 & 20.4 \\
\hline Calcined Solids (wt\%) & 17.4 & 16.8 \\
\hline Density $(\mathrm{g} / \mathrm{mL})$ & 1.19 & 1.11 \\
\hline Nitrite (mg/kg) & 15,500 & 10,500 \\
\hline Nitrate (mg/kg) & 10,500 & 11,300 \\
\hline Oxalate $(\mathrm{mg} / \mathrm{kg})$ & $1,030^{\mathrm{a}}$ & $1,050^{\mathrm{a}}$ \\
\hline Sulfate $(\mathrm{mg} / \mathrm{kg})$ & 1,690 & 1,520 \\
\hline Base Eq. $(\mathrm{Eq} / \mathrm{L}) \mathrm{pH}=7$ & 0.43 & 0.155 \\
\hline $\mathrm{Fe}$ (wt $\%$ of solids) & 19.4 & 17.4 \\
\hline $\mathrm{Na}$ (wt $\%$ of solids) & 12.1 & 11.4 \\
\hline $\mathrm{U}$ (wt $\%$ of solids) & 7.0 & 6.7 \\
\hline
\end{tabular}

${ }^{\text {a }}$ Values from Table 2-1, Table 2-3, and Table 2-6. The oxalate value is from the water dilution of the slurry.

${ }^{\mathrm{b}}$ These results were provided by R. N. Mahannah of DWPF Laboratories. 


\subsection{RHEOLOGY}

\subsection{Description of the Apparatus Used for the Rheological Measurements}

All of the rheological measurements for the sludge slurry sample were obtained using the Haake RV30/M5 system located in Cell 2 of the Shielded Cells Facility. The Haake RV30/M5 system is a controlled shear rate rheometer that is operated remotely in the Shielded Cells environment. A water bath/circulator supplies water to maintain the temperature of the water jacket used to keep the sample at a specified temperature. The M5 measuring head can be equipped with different rotors, with rotor group having a specified measuring cup. The selection of the rotor/cup combination depends on the sample to be analyzed. The specifications for the instrument can be found in a previous publication ${ }^{6}$. A National Institute of Standards and Technology (NIST) traceable Newtonian oil standard $\left(\sim 14 \mathrm{cp} @ 25^{\circ} \mathrm{C}\right)$ was used to verify the functionality/operability of the RV30/M5 system prior to the start and at the completion of a set of samples. All measurements for the Newtonian oil standard were within $\pm 10 \%$ of the standards viscosity. The MVI rotor and MV cup was used in all of the measurements obtained. Specifications for the MVI rotor and cup have been published previously ${ }^{6}$.

The same programming times and shear rate ranges were used for the oil standard and sludge slurry sample. Table 3-1 contains the programming times and shear rate ranges for the sludge slurry samples and the oil standard. Raw data for the flow curves are located in notebook WSRC-NB-2000-00056.

Table 3-1. Programming Times and Shear Rate Ranges Selected for the Sludge Slurry and Standard Oil Samples

\begin{tabular}{|c|c|c|c|c|}
\hline \multirow{2}{*}{} & \multicolumn{2}{|c|}{ Sludge Slurry } & \multicolumn{2}{c|}{ Standard Oil } \\
\cline { 2 - 5 } & $\begin{array}{c}\text { Shear Rate } \\
\text { Range }\left(\mathrm{s}^{-1}\right)\end{array}$ & Time (minutes) & $\begin{array}{c}\text { Shear Rate } \\
\text { Range }\left(\mathrm{s}^{-1}\right)\end{array}$ & Time (minutes) \\
\hline Up Curve & $0-800$ & 5 & $0-800$ & 5 \\
\hline Hold & 800 & 1 & 800 & 1 \\
\hline Down Curve & $800-0$ & 5 & $800-0$ & 5 \\
\hline
\end{tabular}

\subsection{March 2004 SB3 Sludge Slurry Observations and Rheology Measurements}

After the dip samples had been combined and mixed, a sample $(\sim 125 \mathrm{~mL})$ was removed for rheology measurements. The sludge slurry sample was mixed and poured into the measuring cup. While pouring the samples into the measuring cup, a visual observation of the sample was noted. The sludge slurry sample appeared to be dark brown and very fluid. No clumps were observed while pouring the sample into the measuring cup. Once the sample was placed into the measuring cup, the in-cell camera was used to look inside the measuring cup. Several air bubbles appeared to be readily popping at the surface of the sample. The majority of the air bubbles were small (less than $\sim 1 / 16$ inches in diameter). The measuring cup was loaded into the instrument and the measurement was successfully completed. All subsequent measurements were performed in the same fashion and were also successfully completed.

The raw data from the rheometer (up flow curve only) for the sludge slurry is plotted in Figure 3-1. The plotted data, specifically the shear rate, is that of a Newtonian fluid and has not been corrected. The complete data set in Figure 3-1 was curve fitted using the Bingham Plastic model and was plotted against 
the DWPF operating region along. The DWPF operating region was created by using the Bingham Plastic parameters (consistency and yield stress) provided in reference DPSTD-80-38- ${ }^{7}$ and the Bingham Plastic equation $\left(\tau_{\text {upper }}(P a)=0.012 \cdot \dot{\gamma}+10\right)$ and lower $\left(\tau_{\text {lower }}(P a)=0.004 \cdot \dot{\gamma}+2.5\right)$. The Bingham Plastic model is defined as:

$$
\mathrm{Tau}=\mathrm{Tau}_{\mathrm{o}}+\eta \mathrm{D} \text { or }\left\{\tau_{B P}\left(\frac{\text { dynes }}{\mathrm{cm}^{2}}\right)=\frac{\eta}{100} \cdot \dot{\gamma}+\tau_{o} \text { or } \tau_{B P}(P a)=\eta \cdot \dot{\gamma}+\tau_{o}\right\}
$$

Where: $\quad \operatorname{Tau}(\tau)=$ Shear stress $\left\{\right.$ Dynes $/ \mathrm{cm}^{2}$ or $\left.\mathrm{Pa}\right\}$

$\operatorname{Tau}_{\mathrm{o}}\left(\tau_{\mathrm{o}}\right)=$ Shear stress at $\mathrm{D}=0 \mathrm{~s}^{-1}\left\{\right.$ Dynes $/ \mathrm{cm}^{2}$ or Pa $\}$ or Yield Stress

$\eta=$ Consistency $\{$ centipoise $=\mathrm{cP}$ or Pa-sec $\}$

$\mathrm{D}(\gamma)=$ shear rate $\left\{\mathrm{s}^{-1}\right\}$

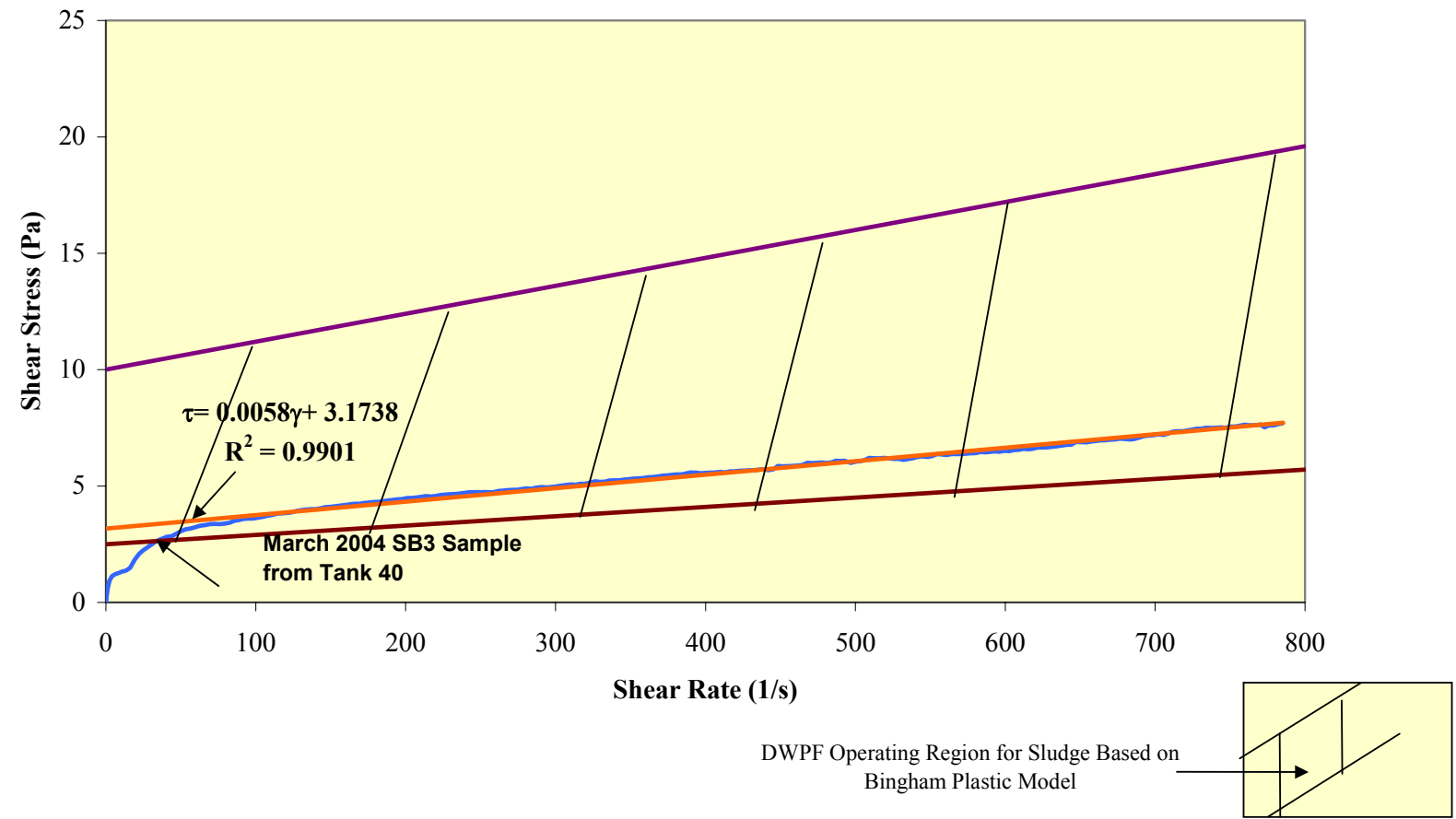

Figure 3-1. Uncorrected Flow Curve for the March 2004 SB3 Sludge Slurry Sample Compared to the DWPF Operating Region

As seen in Figure 3-1, the sample flow curve is within the DWPF operating region for the sludge slurry. The sample was fitted using the Bingham Plastic model from a shear rate range of 40 to $785 \mathrm{sec}^{-1}$. Table 3-2 contains the results of the sludge slurry samples, the SRTC SB3 qualification sample ${ }^{8}$, and the DWPF operating region. The table includes weight percent solids, insoluble solids, yield stress, consistency, and $\mathrm{pH}$. If a value is not available, "N/A" is used in the table. 
WSRC-TR-2004-00208

Revision 0

Table 3-2. Summary of the Results Obtained from the SB3 Sludge Slurry Samples Compared to the SRTC SB3 Qualification Sample and the DWPF Operating Region

\begin{tabular}{|c|c|c|c|c|c|}
\hline Sample ID & $\begin{array}{c}\text { Total } \\
\text { Solids } \\
\text { (wt.\%) }\end{array}$ & $\begin{array}{c}\text { Insoluble } \\
\text { Solids } \\
\text { (wt.\%) }\end{array}$ & $\begin{array}{l}\text { Yield Stress } \\
\left(\text { dynes } / \mathbf{c m}^{2}\right)\end{array}$ & $\begin{array}{c}\text { Consistency } \\
\text { (cp) }\end{array}$ & pH \\
\hline 2004 SB3 Dip Samples & 20.0 & 14.8 & 33 & 5.6 & 12.6 \\
\hline $\begin{array}{c}\text { SRTC SB3 Qualification } \\
\text { Sample }\end{array}$ & 27.2 & 17.1 & 40.6 & 7.37 & 13.4 \\
\hline DWPF Operating Region & $13-19$ & N/A & $25-100$ & $4-12$ & $\mathrm{~N} / \mathrm{A}$ \\
\hline
\end{tabular}

As can be seen in Table 3-2, the 2004 SB3 sample is within all of the DWPF operation parameters listed except for the total weight percent solids. The total weight percent solids value is higher due to the Canyon additions $(\mathrm{Pu} / \mathrm{Gd}, \mathrm{Am} / \mathrm{Cm}$, and $\mathrm{Np})$ to Tank 40. DWPF Engineering evaluated these additions and has accepted the higher $w \mathrm{t} \%$ total solids 9 . 
WSRC-TR-2004-00208

Revision 0

This page intentionally left blank. 


\subsection{CONCLUSIONS}

- Coal content of the Tank 40 sample was similar to that predicted using analysis of the Tank 51 qualification sample.

- Most, if not all, the sulfur was soluble and in the form of sulfate. IC analysis of the water dilution of the slurry is adequate for sulfate determination in the SB3 sample.

- Most, if not all, the oxalate was soluble. IC analysis of the water dilution of the slurry is adequate and the acid strike method is not necessary for oxalate determination in SB3.

- The yield stress and the consistency for the March 2004 SB3 sample is within the DWPF Operating Region. The consistency was $5.6 \mathrm{cp}$ and yield stress was $33 \mathrm{dynes} / \mathrm{cm}^{2}$. 
WSRC-TR-2004-00208

Revision 0

This page intentionally left blank. 


\subsection{REFERENCES}

1. D.R. Click, C.J. Coleman, "Measured Coal Concentration in the First, Second and Third Samples of Mixed Tank Seven Slurry Using Loss on Ignition (LOI) and Thermal Gravimetric Analysis (TGA)." SRT-ADS-2003-0005.

2. D.R. Click, "Measured Coal Concentration in the Initial Tank Fifty One Sample By Thermogravimetric Analysis (TGA)." SRT-ADS-2003-0392.

3. Pareizs, J. M.; Koopman, D. C.; Click D.R., Cozzi A.D., Bibler N.E. Sludge Batch 3 Qualification in the SRTC Shielded Cells, WSRC-TR-2004-00050; Savannah River Site: Aiken, SC, May 2004.

4. Fowler, J. R. Estimate of Maximum Amount of Reducing Agents and Sand in SRP Waste for DWPF TDS, DON'T SAY IT - WRITE IT communication from J. R. Fowler to J. R. Wiley; Savannah River Site: Aiken, SC, September 9, 1980.

5. Bibler, N. E.; Hay, M. S. Total and Soluble Sulfur in a Sample From Tank 40 (Sludge Batch 2) and a Composite of Samples From Tank 51 (Sludge Batch 3), WSRC-TR-2004-00092; Savannah River Site: Aiken, SC, March 2004.

6. Fellinger, T. L.; Koopman, D. C. Rheological and Physical Data Results for Tank 40 Radioactive Samples Compared to Nonradioactive Tank 40 Samples (U), WSRC-TR-2002-00302; Savannah River Site: Aiken, SC, October 18, 2002.

7. Technical Data Summary for the Defense Waste Processing Facility: Sludge Plant, DPSTD-80-38-2; Savannah River Site; Aiken, SC, 1980.

8. Stone, M. E. SB2/SB3 Washing and Blending Recommendations, Interoffice Memorandum SRTGPD-2003-00131; Savannah River Site: Aiken, SC, October 15, 2003.

9. Rios-Armstrong, M. A. EVALUATION OF EXTENDED SLUDGE PROCESSING SLUDE BATCH 3 COMPLIANCETO DWPF WASTE EXCEPTANCE CRITERIA, X-ESR-S-00016; Savannah River Site: Aiken, SC, March 2004. 